\title{
DANTE's Medical Knowledge: The Case of INFERNO, Canto XXX
}

\author{
Luigi Roffi \\ Department of Internal Medicine, ASST Nord Milano, Milan, Italy \\ Email: luigi.roffi@asst-nordmilano.it
}

How to cite this paper: Roffi, L. (2018). DANTE's Medical Knowledge: The Case of INFERNO, Canto XXX. Advances in Historical Studies, 7, 15-21.

https://doi.org/10.4236/ahs.2018.71002

Received: November 20, 2017

Accepted: March 25, 2018

Published: March 28, 2018

Copyright $\odot 2018$ by author and Scientific Research Publishing Inc. This work is licensed under the Creative Commons Attribution International License (CC BY 4.0).

http://creativecommons.org/licenses/by/4.0/

\begin{abstract}
The Divine Comedy, by Dante Alighieri, describes an imaginative journey in afterlife. In Hell, canto XXX, Dante meets the falsifiers and sees a man who has the shape of a lute, a rotting face, and an abdomen bloated by "dropsy". This horribly deformed sinner is Master Adam, who counterfeited Florentine money, and for this crime was burned at the stake. Previous critics had ascribed Master Adam's punishment to various real or imaginary diseases, but an alternative possibility is that it may represent one of the most ancient, yet accurate, descriptions of tense ascites in the literature.
\end{abstract}

\section{Keywords}

Dante Alighieri, Hepatic Cirrhosis, Ascites, History of Medicine

\section{Introduction}

The Divine Comedy (started in 1304 or in 1307 and completed in 1320) by Dante Alighieri (Firenze, 1265-Ravenna, 1321), a preeminent work of Italian culture and one of the world's greatest works of literature, that inspired other literary giants like Chaucer and Milton (Kuhns, 1898), describes an imaginative journey in afterlife. It is divided into three parts (Cantica): Hell (Inferno), Purgatory (Purgatorio), and Heaven (Paradiso). In Inferno canto XXX, Dante meets the counterfeiters (falsifiers of People, Coins or Words). In particular, he sees a man who has the shape of a lute, a rotting face, and an abdomen bloated by a disease called "dropsy" (“... And one I saw, who like a lute were shaped/if he had only had his groin cut off/down in the region where a man is forked/The heavy dropsy which unmates the limbs/in such a way with ill-digested humor/that face and paunch no longer correspond.../Inferno XXX, 49-54) (Langdon, 1918). This horribly deformed sinner identifies himself as Master Adam, who counterfeited 
Florentine money, and for this crime was burned at the stake in Florence in 1281. Precise identity of this individual is unknown, but he is likely an Englishman (magistro Adam de Anglia) (Ledda, 2011).

Master Adam's punishment is a constant craving for water (“... and now, alas, I crave a drop of water/The little brooks which toward the Arno run/down from the Casentino's green-clad hills,/and render all their channels cool and fresh,/are evermore before me, nor in vain/because their image makes me drier far/than this disease, which strips my face of flesh... Inferno XXX, 63-69) (Langdon, 1918). Extreme fatigue is another feature of this damned soul (“... but what is that to me whose limbs are bound?/If only I were still so light of foot,/that I could in a hundred years advance/one inch, I'd be already on the road... Inferno canto XXX, 81-84) (Langdon, 1918). At some point, Master Adam introduces Sinon, who had tricked the Trojans taking the wooden horse statue filled with Achaean warriors inside their city walls. Sinon feels insulted for not being named explicitly by Master Adam, and reaches out to slap his bloated belly, which sounds like a drum (Figure 1).

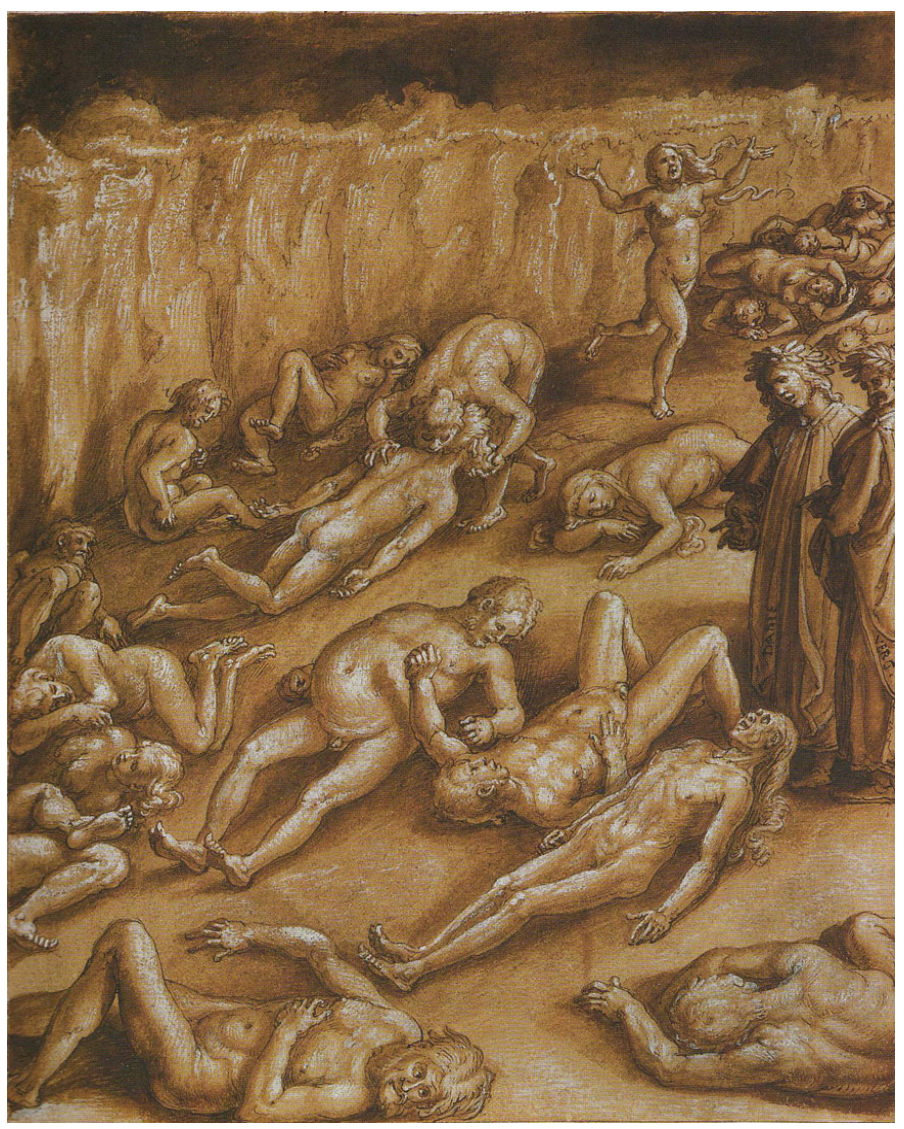

Figure 1. Dante Alighieri (1265-1321): Divine Comedy (1304/1307-1320): Punishment of the Falsifiers. Bickering between Master Adam and Sinon: And one of them, who felt aggrieved, perhaps, at being named so darkly, smote the speaker upon his hard stiff belly with his fist. It made a sound, as it had been a drum (Inferno XXX, 100-103). Jan Van der Straet (detto Giovanni Stradano o Stradanus) (Bruges, 1523-Firenze, 1605). 


\section{Master Adam's Disease}

Previous critics of The Divine Comedy had ascribed Master Adam's punishment to several different real or imaginary diseases, oddly with the exception of a liver disease. Only recently some authors mentioned the possibility of a liver disease (Riva et al., 2015; Bartoli, 2007; Bianucci, 2017). In fact, this may be one of the most ancient, yet accurate, descriptions of symptoms and signs of tense ascites in the literature. Cirrhosis impairs hepatic function and causes structural changes leading to portal hypertension. Ascites is the most widely recognized complication (Tsochatzis, 2014). Here the concise, wonderful description of ascites given by Dame Sheila Sherlock: "The portal hypertension serves to localize the fluid retention in the peritoneal cavity rather than in the peripheral tissues... The two most important factors in the development of ascites are failure of the liver to synthesize albumin-and hence a lowered plasma osmotic pressure-and portal hypertension. More fluid enters the peritoneal cavity than leaves it and ascites develops... The patient is sallow and dehydrated. Sweating is diminished. Muscle wasting is profound. The thin limbs with protuberant belly lead to description of the patient as a "spider man". The abdomen is distended not only with fluid but also by air in the dilated intestines... In the management of ascites abdominal girth is unreliable for gaseous distension is common." (Sherlock, 1985) Malnutrition and consequent sarcopenia are common in patients with cirrhosis, and worsen other complications, quality of life, survival, and outcome after liver transplantation. The pathogenesis of sarcopenia in cirrhosis is multifactorial and not fully understood. The mechanisms that contribute to sarcopenia include inadequate dietary intake, metabolic disturbances, and malabsorption. Because cirrhotic liver tissue exhibits impaired synthesis and storage of glycogen, relatively short periods of fasting in patients with cirrhosis result in the breakdown of fat and muscle and promote gluconeogenesis from non-carbohydrate sources: this can lead to muscle wasting (O’Brien \& Williams, 2008; Kim \& Jang, 2015). Hyponatremia is the most common electrolyte disorder in patients with cirrhosis (Guevara \& Ginès, 2010). Its signs and symptoms may include nausea and vomiting, headache, confusion, loss of energy and fatigue, restlessness and irritability, muscle weakness, spasms or cramps, seizures, coma (Nusrat et al., 2014).

\section{Dante's Medical Knowledge}

Many ancient writings report the depth of Dante's medical knowledge (Riva, et al., 2015). Not much is known about Dante's education, though. As a child, he presumably studied at home or in a chapter school connected to a church or monastery in Florence. It is certain that he studied Tuscan poetry, the "Sicilian school poetry" (Scuola poetica Siciliana), the Provençal poetry of the troubadours, and classical Latin writers, including Cicero, Ovid, and most of all, Virgil. Moreover, based on what we know about secondary education in late Middle Ages, he likely studied Latin grammar, rhetoric and philosophy (Trivium), and arithmetic, geometry, astronomy and music (Quadrivium). Later, he studied 
philosophy at religious schools, such as the Dominican one in Santa Maria Novella, in Florence. The possibility that he also received a medical training is corroborated by some historical facts. First, in 1295 he became a member of the Guild of Physicians and Apothecaries (Ars Medicorum et Apothecariorum). Actually this was neither a surprising nor an inappropriate choice for a man of letters, as books were sold by apothecary shops at the time. In fact this guild included also painters like Cimabue, Giotto, Paolo Uccello, Masaccio and others. Second, Dante is portrayed by Giotto (1267-1337) in the Bargello chapel (Cappella del Podestà), by Domenico di Michelino (1417-1491) in the Florence's Cathedral, and also by Andrea del Castagno, Luca Signorelli and others, wearing the red gown and hood worn by medieval physicians (Figure 2). Third, Villani and Boccaccio claimed that Dante studied in Bologna and precise allusions to this city in his works convince us that he resided there for a considerable time. It seems likely, though not clearly documented, that he visited Paris to complete

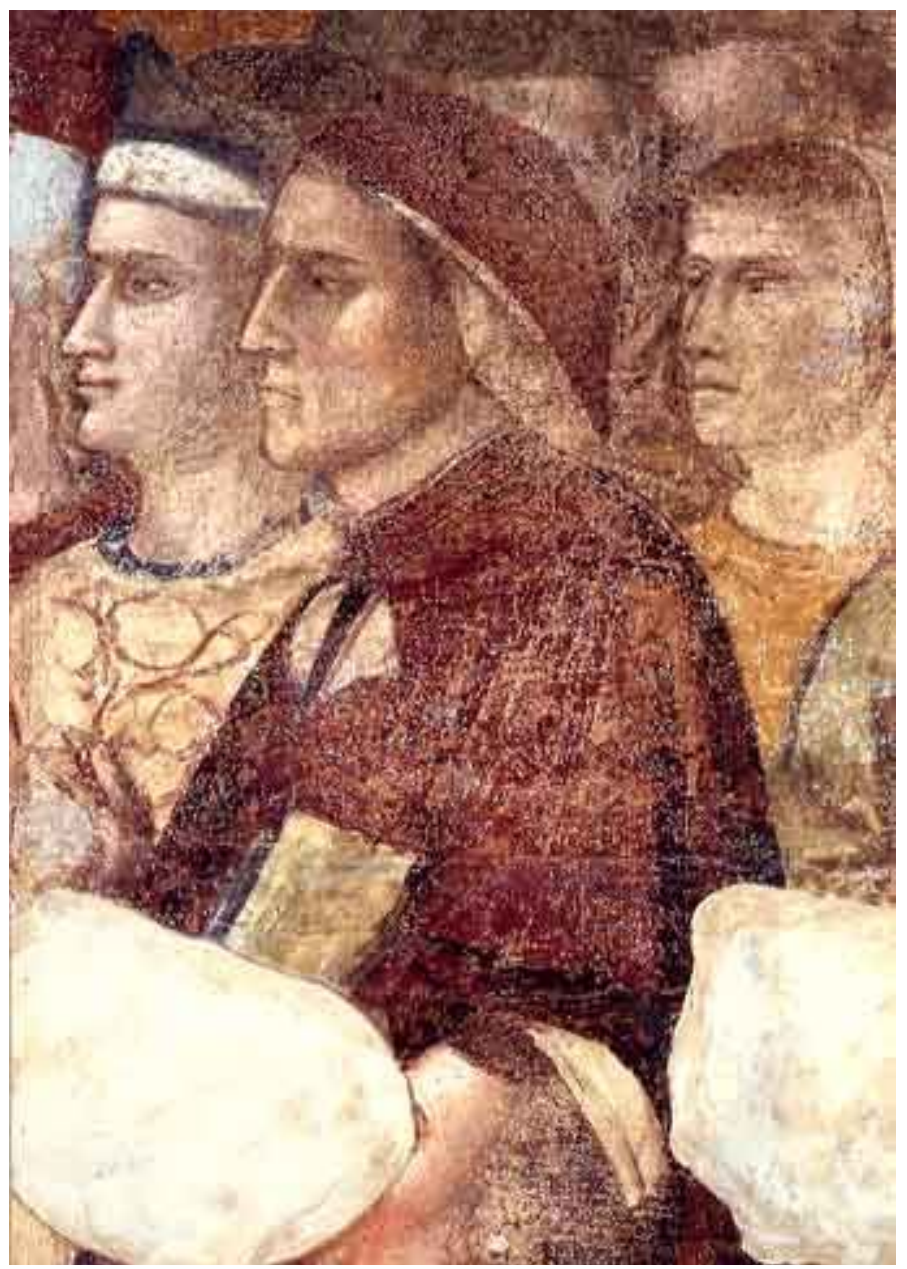

Figure 2. Dante Alighieri, by Giotto di Bordone, c. 1335. Detail from a fresco in the Podestà Chapel in the Palazzo del Bargello by Giotto, who was considered by Dante to have revolutionized the art of painting in the 14th century: In painting Cimabue thought he held the field, and now it's Giotto they acclaim - the former only keeps a shadowed fame (Purgatory XI, 94-96). 
his curriculum of studies (Gurgone, 2014). Bologna, as well as Paris, Montpellier and Oxford, hosted the first centers for advanced studies in the field of liberal arts, theology, law and medicine. Furthermore, medicine was not a formal area of study and the curriculum of academic medicine was fundamentally based on translated texts and treatises attributed to Hippocrates and Galen, as well as on Arabic medical texts. For instance, we know that Bologna University owned 15 volumes by Galen, four by Hippocrates, two by Ibn-Sina (Avicenna) and one by Ibn-Rushd (Averroè). Interestingly enough, Dante mentions all these authors in the Comedy (... Galen, Hippocrates, and Avicenna,/Averroes, who the great Comment made... Inferno canto IV, 142-143) (Langdon, 1918). The required number of years to become a licensed physician varied among universities. The University of Bologna, for example, required three years of philosophy, three years of astrology, and four years of attending medical lectures (Bartoli, 2007). Lastly, in The Divine Comedy, Dante demonstrates extensive medical knowledge that would qualify him as a physician, even if he never practiced this art (Riva, et al., 2015; Gilson, 2007).

\section{4. "Ascites" in Ancient Medical Literature}

The word "dropsy" refers to any accumulation of liquids in the serous cavities or connective tissues of the body, and it appeared in English in the late 13th century, whereas "ascites"-derived from the ancient Greek term askos (ацкоц) meaning a leather bag used to carry liquids-entered the language a century later, referring specifically to abdominal dropsy (Ruben, 2004). However, the phenomenon of fluids accumulating in the abdominal cavity had already been known since ancient times. Swelling of the abdomen with fluid is described in the Old Testament, in Egyptian Papyrus Ebers (from the reign of Amenophis I, ca. $1550 \mathrm{BCE}$ ), and in an ancient Indian medical treatise which probably dates around 1500-1300 BCE (Ruben, 2004). Hippocrates realized that not only did abdominal dropsy derive directly from the diseased liver, but it was also a fatal complication, as he states in his Aphorisms (VII:55) that "When the liver is filled with water and bursts into the epiploon (the omentum), in this case the belly is filled with water and the patient dies" (Ruben, 2004). A century later, Erasistratos of Chios, active in Alexandria, proposed a pathophysiological explanation for hepatic ascites that was not too far from the truth. He ascribed ascites to a rock-hard liver: “...as water cannot accumulate... in any other way than from narrowness of the blood vessels going through the liver". According to him, congestion (hyperemia) or plethora, as he named it, was a main cause of ascites (Ruben, 2004; Dawson, 1960; Dobson, 1925). The original writings of Erasistratus are lost, but many of his ideas have been preserved in Galen's writings, who quoted him frequently, usually to disagree with him (Ruben, 2004). Of course, apart from the description in the Bible, most of these records were unknown to Dante, but he was probably familiar with Hippocrates' description of dropsy and certainly knew Galen writings and De proprietatibus rerum by Bartolomeo An- 
glico, a popular text employed by Dante repeatedly in his writings: “... extenditur venter [...], collum et extrema efficiuntur gracilia... Hydropicus est gravis et ponderosus et sitibundus, qui quanto plus bibit, tanto plus sitit, et quanto plus bibit, tanto [...] amplius inturgescit' (...bloated abdomen....neck and limbs become very skinny.....patients with ascites become heavy, weighty and thirsty, in a way that the more they drink, the more thirsty they feel... and the more bloated their abdomens become) (Ledda, 2011).

\section{Conclusion}

We cannot ascribe any etiopathogenetic medical knowledge to Dante, since the causes of ascites were only discovered at the end of the XX century. Nevertheless, in Inferno canto XXX, he was able to turn into verses with utmost accuracy the physical semeiotics of the disease, and also the psychological attitude of patients.

"Myths and tradition, literature and fine arts... can provide valuable information on medical knowledge in the ancient ages, sometimes more useful than the writings of ancient physicians" (Tiniakos et al., 2010). Inferno, canto XXX, may be an appropriate example of it.

\section{Acknowledgements}

The Author acknowledges his debt to Giuseppe Ledda and Laura Pasquini, Università di Bologna, and Giuseppe Frasso, Università Cattolica Milano for advice on literature; to Michele Riva for hints and tips on approach and to Bettina Beck for English revision.

\section{Conflict of Interest}

No relationship that might occur as a conflict of interest.

\section{References}

Bartoli, V. (2007). L'idropisia del maestro Adamo in Inferno XXX. Tenzone, 8, 11-29.

Bianucci, R., Perciaccante, A., Charlier, P., Appenzeller, O., \& Lippi, D. (2017). Mastro Adamo, the Counterfeiter of Coins, Had Cirrhosis as Described in Dante's Inferno (13th Century Florence). European Journal of Internal Medicine, 39, 35-56. https://doi.org/10.1016/j.ejim.2017.01.022

Dawson, A. D. (1960). Historical Notes on Ascites. Gastroenterology, 39, 790-791.

Dobson, J. F. (1925). Erasistratos. Proceedings of the Royal Society of Medicine, 18, 825-832.

Giacomo, G. (2014). Anatomical Knowledge in the Late Middle Ages: Considerations over the Inferno XXVIII of The Divine Comedy. Acta Medica Mediterranea, 30, 13.

Gilson, S. A. (2007). The Anatomy and Physiology of the Human Body in the Comedia. In J. C. Barnes, \& J. Petrie (Eds.), Dante and the Human Body: Eight Essays (pp. 11-42). Dublin: UCD Foundation for Italian studies/Four Courts Press.

Guevara, M., \& Ginès, P. (2010). Hiponatremia en la cirrosis hepática: patogenia y tratamiento [Hyponatremia in Liver Cirrhosis: Pathogenesis and Treatment]. Endocrino- 
logía y Nutrición, 57, 15-21. https://doi.org/10.1016/S1575-0922(10)70018-8

Kim, H. Y., \& Jang, J. W. (2015). Sarcopenia in the Prognosis of Cirrhosis: Going beyond the MELD Score. World Journal of Gastroenterology, 21, 7637-7647. https://doi.org/10.3748/wjg.v21.i25.7637

Kuhns, O. (1898). Dante's Influence on Milton. Modern Language Notes, 13, 1-6. http://www.jstor.org/stable/2917074 https://doi.org/10.2307/2917074

Langdon, C. (1918). The Divine Comedy of Dante Alighieri. The Italian Text with a Translation in English Blank Verse. Vol. 1 (Inferno). Cambridge: Harvard University Press.

Ledda, G. (2011). Commento a Inferno XXX Lectura Dantis Andreapolitana. Scotland: St Andrews.

Nusrat, S., Khan, M. S., Fazili, J., \& Madhoun, M. F. (2014). Cirrhosis and Its Complications: Evidence Based Treatment. World Journal of Gastroenterology, 20, 5442-5460. https://doi.org/10.3748/wjg.v20.i18.5442

O'Brien, A., \& Williams, R. (2008). Nutrition in End-Stage Liver Disease: Principles and Practice. Gastroenterology, 134, 1729-1740.

https://doi.org/10.1053/j.gastro.2008.02.001

Riva, M. A., Cambioli, L., Castagna, F. et al. (2015). Dante and Cardiology: Physiopathology and Clinical Features of Cardiovascular Diseases in Middle Ages. International Journal of Cardiology, 181, 317-319. https://doi.org/10.1016/j.ijcard.2014.11.225

Ruben, A. (2004). My Cup Runneth Over. Hepatology, 40, 503-507. https://doi.org/10.1002/hep.20361

Sherlock, D. S. (1985). Diseases of the Liver and Biliary System (7th ed., Chapter 10). Oxford: Blackwell Scientific Publication.

Tiniakos, D. G., Kandilis, A., \& Geller, S. A. (2010). Tityus: A Forgotten Myth of Liver Regeneration. Journal of Hepatology, 53, 357-361. https://doi.org/10.1016/j.jhep.2010.02.032

Tsochatzis, E. A., Bosch, J., \& Burroughs, A. K. (2014). Liver Cirrhosis. The Lancet, 383, 1749-1761. https://doi.org/10.1016/S0140-6736(14)60121-5 